\title{
Gonadotropin-secreting cells in ovariectomized rats treated with different oestrogen receptor ligands: a modulatory role for ER $\beta$ in the gonadotrope?
}

\author{
J E Sánchez-Criado*, J Martín de las Mulas ${ }^{1 *}$, C Bellido, \\ V M Navarro, R Aguilar, J C Garrido-Gracia, M M Malagón, \\ M Tena-Sempere and A Blanco ${ }^{1}$ \\ Departments of Cell Biology, Physiology and Immunology and ${ }^{1}$ Comparative Pathology, University of Córdoba, Avda. Menendez Pidal s/n, \\ 14004 Córdoba, Spain \\ (Requests for offprints should be addressed to J E Sánchez-Criado; Email: fi1sacrj@uco.es) \\ *(J E Sánchez-Criado and J Martín de las Mulas contributed equally to this work)
}

\begin{abstract}
In the rat, oestrogen is a key regulator of gonadotrophin synthesis and release through activation of oestrogen receptors (ERs). Gonadotropes express $\alpha$ and $\beta$ isoforms of ER and both can activate transcription in response to oestrogen. These experiments were aimed at evaluating the relative contribution of $\operatorname{ER} \alpha$ and $\operatorname{ER} \beta$ on gonadotrope morphology, progesterone receptor (PR) expression and $\mathrm{LH}$ secretion. Ovariectomized rats were daily injected over 3 days with $25 \mu \mathrm{g}$ oestradiol benzoate, 0.3 or $1.5 \mathrm{mg}$ of the selective ER $\alpha$ agonist propylpyrazole triol (PPT) with or without $1.5,3.0$ or $4.5 \mathrm{mg}$ of the selective ER $\beta$ agonist diarylpropionitrile (DPN), DPN alone, and $0 \cdot 3$ or $3 \mathrm{mg}$ of tamoxifen. Controls were given $0 \cdot 2 \mathrm{ml}$ oil. Serum concentration and pituitary content of $\mathrm{LH}$, gonadotrope PR expression, pituitary PR content, and gonadotrope morphology were analyzed by RIA, immunohistochemistry, Western blotting and light and
\end{abstract}

electron microscopy, respectively. Results showed that PPT reversed all consequences of ovariectomy, DPN mimicked the effects of PPT except for its LH-releasing action and tamoxifen had ER $\alpha$-like responses. When combined with PPT, DPN attenuated ER $\alpha$ effects without interfering with its LH-releasing activity. Oestradiol benzoate had similar effects to those of combined PPT and DPN. It is suggested that (i) the structural reorganization of the cytoplasmic organelles provided by oestrogen, and the shrinkage of the ovariectomy-induced hypertrophy of gonadotropes, which precedes the expression of PR, are evoked by ER $\alpha$ and modulated, in a ying-yang fashion, by ER $\beta$; and (ii) the oestrogen-dependent exocytosis of $\mathrm{LH}$, the final step in the secretory process, is dependent on ER $\alpha$ exclusively.

Journal of Endocrinology (2006) 188, 167-177

\section{Introduction}

In the rat, ovarian oestrogen regulates synthesis and release of gonadotrophins acting on intracellular oestrogen receptor (ER) in the gonadotrope. Synthesis and release of gonadotrophins are distinct and differentially regulated events. Whereas biosynthesis is a sophisticated process in the membrane-enclosed intracellular organelles - rough endoplasmic reticulum (RER) and Golgi complex - of the gonadotrope (Pierce 1988), release is a mere regulated exocytosis prompted by the physiological secretagogue gonadotrophin-releasing hormone (GnRH; Fink 1979, 1988). Removal of oestrogen by ovariectomy (OVX) in the rat induces profound effects on the synthesis and release of gonadotrophins. After OVX, pituitary content and release of gonadotrophins increase as time after OVX increases, and gonadotropes become hypertrophic with disorganization of intracellular organelles (OVX cells; Genbacev \& Pantic 1975, Garner \& Blake 1981). Also, as a consequence of the lack of oestrogen, the expression of progesterone receptor (PR) falls (SánchezCriado et al. 2004, 2005). Oestrogen treatment reverses the effects of OVX on gonadotrope size and morphology, PR expression and secretion of gonadotrophins (Genbacev \& Pantic 1975, Low 1988, Sánchez-Criado et al. 2004).

Rat gonadotropes express ER $\alpha$ and $\operatorname{ER} \beta$ isoforms (Mitchner et al. 1998, Vaillant et al. 2002, Sánchez-Criado et al. 2005). ER isoforms are encoded by separate genes and both can activate transcription in response to oestrogen (Kuiper et al. 1997, McInerney et al. 1998). After oestrogen binding to ERs, ER modulates the transcription of target genes and protein expression (Murdoch \& Gorski 1991). This is followed at the pituitary level in ovariectomized rats by shrinkage of gonadotropes 
and reorganization of the intracellular organelles, increase in gonadotrope responsiveness to the hypothalamic decapeptide GnRH and, through the activation of oestrogen-dependent PR (Turgeon \& Waring 1994, Sánchez-Criado et al. 2005), GnRH self-priming (Fink 1995, 2000). By using the selective ER $\alpha$ and ER $\beta$ agonists, propylpyrazole trial (PPT) and diarylpropionitrile (DPN), respectively, in ovariectomized rats, we showed that selective activation of $\mathrm{ER} \alpha$ restores the PRdependent positive feedback of oestrogen on gonadotrophin release, sensitizes the pituitary to the secretagogue GnRH, and induces GnRH self-priming (SánchezCriado et al. 2004). In addition to these effects on gonadotrophin release, ER $\alpha$ induces PR mRNA and protein expression and reduces the number and size of OVX cells. In contrast, selective activation of ER $\beta$ lacks releasing effects while it induces PR expression, not followed by GnRH self-priming, and reduces the number and size of OVX cells (Sánchez-Criado et al. 2004).

The existence of steroid receptor subtypes is becoming more the rule than the exception, and there is increasing evidence to suggest that the presence of receptor isoforms is not a case of redundancy but rather the indication of an additional level of regulation at the target tissue (Keightley 1998). The aim of the present study was to evaluate, in ovariectomized rats, the effect of different ER ligands (the cognate ligand oestradiol benzoate, selective ER $\alpha$ and/or ER $\beta$ agonists and the selective ER modulator tamoxifen (TX)) on: (i) light and electron microscopy of the gonadotrope morphology; (ii) PR protein expression and content in the gonadotrope and the anterior pituitary, respectively; and (iii) serum concentration and pituitary content of luteinizing hormone (LH).

\section{Materials and Methods}

\section{Animals and treatments}

Adult female Wistar rats weighing 190-210 g were used. Rats were housed under a $14 \mathrm{~h}: 10 \mathrm{~h}$ light/dark cycle (light on at $05: 00 \mathrm{~h}$ ) and $22 \pm 2{ }^{\circ} \mathrm{C}$ room temperature, with access ad libitum to rat chow and tap water. All rats were ovariectomized under light ether anesthesia at random stages of the oestrous cycle. Two weeks after surgery, ovariectomized rats were injected daily at 09:00 h over 3 days with (i) $0.2 \mathrm{ml}$ oil vehicle (control group), (ii) $25 \mu \mathrm{g}$ of oestradiol benzoate (EB; Sigma Chemical Co.) to obtain maximal oestrogen effects, (iii) 0.3 or $1.5 \mathrm{mg}$ of the ER $\alpha$-subtype-selective ligand PPT (Tocris Cookson, Avonmouth, Avon, UK; Stauffer et al. 2000) with or without $1.5 \mathrm{mg}$ of the ER $\beta$-subtype-selective ligand DPN (Tocris Cookson; Meyers et al. 2001), (iv) DPN alone, or (v) 0.3 or $3 \mathrm{mg}$ of the selective ER modulator TX (Sigma Chemical Co.). Doses of ER-selective ligands used were chosen based on previous studies showing that
PPT and DPN displayed full oestrogen activity and absence of ER $\alpha$ activation, respectively (Sánchez-Criado et al. 2004, Tena-Sempere et al. 2004). At 09:00 h on the day after treatments rats were decapitated, their trunk blood collected and serum stored at $-20{ }^{\circ} \mathrm{C}$ until quantified for LH by RIA. The anterior pituitaries were dissected out and processed for (i) pituitary LH content determination, (ii) immunohistochemistry and electron microscopy studies, and (iii) Western blot analysis. Additional ovariectomized rats treated with $1.5 \mathrm{mg}$ PPT were injected with $0.2 \mathrm{ml}$ oil or $1.5,3 \cdot 0$, or $4.5 \mathrm{mg}$ DPN and their pituitaries evaluated for immunohistochemistry. All experimental protocols were approved by the Ethical Committe of the University of Córdoba. Experiments were performed in accordance with the rules of laboratory animal care and international law on animal experimentation.

\section{Pituitary LH content determination}

For LH content determination, anterior pituitaries were homogenized in $1 \mathrm{ml}$ RIA buffer and subjected to ultrasonic treatment. Samples were centrifuged at $2800 \boldsymbol{g}$ for $10 \mathrm{~min}$ and the supernatants frozen at $-20{ }^{\circ} \mathrm{C}$ until assayed by RIA.

\section{RIA of $L H$}

Serum concentration and pituitary content of LH were measured in duplicate by RIA using a double-antibody method with kits supplied by the National Institutes of Health (Bethesda, MD, USA) and a previously described microassay method (Sánchez-Criado et al. 1990). Rat LH-I-10 was labelled with ${ }^{125} \mathrm{I}$ by the chloramine $\mathrm{T}$ method. All serum and pituitary samples were assayed in the same assay. The intra-assay coeffient of variation was $8 \%$. Assay sensitivity was $3.75 \mathrm{pg} /$ tube. LH concentration and content were expressed as $\mathrm{ng} / \mathrm{ml}$ serum or $\mu \mathrm{g} / \mathrm{mg}$ pituitary of the reference preparation LH-rat-RP-3.

\section{Tissue preparation for light and electron microscopy}

Anterior pituitaries from four rats/group were divided into half. For light microscopy, four hemipituitaries/group were fixed in $10 \%$ buffered formalin and embedded in paraffin wax. For electron microscopy, small fragments from each of the remaining four hemipituitaries/group were fixed in $2.5 \%$ glutaraldehyde in $0.1 \mathrm{M}$ phosphate buffer $(\mathrm{pH} 7 \cdot 4)$ followed by post-fixation in $1 \%$ osmium tetroxide in distilled water for $2 \mathrm{~h}$. Tissue fragments were then embedded in Araldite and cut at $0 \cdot 1 \mu \mathrm{m}$ with an ultramicrotome. Current functional ultrastructural characteristics of membrane-enclosed intracellular organelles (RER, Golgi complex, and secretory vesicles) in gonadotrophin-secreting cells (Childs 1986) were evaluated. 


\section{Immunohistochemistry of pituitary $P R$}

The immunohistochemical study was performed on dewaxed and rehydrated $3 \mu \mathrm{m}$ thick tissue sections of formalin-fixed, paraffin-embedded tissue samples. The commercial mouse monoclonal anti-human PR antibody clone PR10A9, which is raised against the recombinant hormone-binding domain in the $\mathrm{C}$-terminal region of human PR (Immunotech, Marseille, France; diluted 1:15 000), and the avidin-biotin peroxidase complex technique (Vector Laboratories, Burlingame, CA, USA), were used as previously described (Sánchez-Criado et al. 2004). Tissue sections from similarly processed samples of rat uterus and human breast carcinoma were used as positive controls. The specificity of the PR antibody was shown by the lack of staining after pre-incubation of tissue sections of rat uterus and pituitaries from ovariectomized rats treated with EB with $10^{-9}, 10^{-7}$ and $10^{-5} \mathrm{M}$ of the cognate ligand for $1 \mathrm{~h}$ at $37^{\circ} \mathrm{C}$. Substitution of the specific primary antibody by mouse ascitic fluid at the same dilution as the specific primary antibody in tissue sections of the cases under study was used as a negative control. Several dilutions of the PR10A9 monoclonal antibody were tested and the optimal dilution was established at 1:15 000, because it gave the highest intensity of nuclear staining with the lowest background staining in pituitary and uterus (Sánchez-Criado et al. 2004). Nuclear counterstaining was performed with Mayer's haematoxylin in all cases.

\section{Identification of gonadotropes and morphometric study}

All pituitary cells expressing PR were identified as activated gonadotropes because gonadotropes are the only pituitary cells expressing PR (Fox et al. 1990). In addition, gonadotropes not expressing PR were identified because they had the size and morphological features of OVX cells (hypertrophied gonadotropes; Garner \& Blake 1981, Childs 1986). The size of pituitary cells (their perimeter) was evaluated in digitalized images of PR-immunostained tissue sections using the VISILOG 5 program as described previously (Blanco et al. 2001). Twenty digitalized fields per hemipituitary were evaluated. Each field was digitalized at $400 \times$ magnification.

\section{Protein extraction and Western blotting for pituitary PR content}

Relative levels of PR protein were assessed by Western blot using a commercial polyclonal antibody (PR C-20: sc-539; Santa Cruz Biotechnology), and previously published protocols (Guerra-Araiza et al. 2003), with minor modifications. Briefly, pituitaries (four/group) were collected immediately upon decapitation, snap-frozen and stored at $-80{ }^{\circ} \mathrm{C}$. Tissue fragments were homogenized in TDG lysis buffer containing $10 \mathrm{mM}$ Tris $/ \mathrm{HCl}$,
$1 \mathrm{nM}$ dithiothreitol, 30\% glycerol, 1\% Triton X-100, $15 \mathrm{mM}$ sodium azide and $1 \mathrm{mM}$ EDTA, supplemented with the protease inhibitor mix CLAP (5 mg/ml chymostatin, $5 \mathrm{mg} / \mathrm{ml}$ leupeptin, $5 \mathrm{mg} / \mathrm{ml}$ antipain and $5 \mathrm{mg} / \mathrm{ml}$ pepstatin-A) and $1 \mathrm{mM}$ PMSF. After protein quantification using the Bradford method, equal amounts of proteins $(150 \mu \mathrm{g} / \mathrm{lane})$ were resolved by electrophoresis in $10 \% \mathrm{SDS} / \mathrm{PAGE}$ gels at $75 \mathrm{~V}$. Gels were transferred to nitrocellulose membranes (Amersham Biosciences) overnight at $30 \mathrm{~V}$. After transfer, membranes were blocked for $2 \mathrm{~h}$ in $5 \%$ non-fat dry milk in Tris-buffered saline, and incubated overnight at $4{ }^{\circ} \mathrm{C}$ in the presence of $2 \mu \mathrm{g} / \mathrm{ml}$ primary anti-PR antibody. After exhaustive washing, membranes were incubated for $1 \mathrm{~h}$ with goat anti-rabbit IgG conjugated with horseradish peroxidase. Proteins were detected by chemiluminescence, using the ECL kit (Amersham Biosciences) following manufacturer's instructions.

As a control for the specificity of PR immunodetection, reactions with the primary antibody omitted were routinely conducted. In addition, as an internal control for the amount of protein loaded per lane, membranes were reprobed with a goat anti- $\beta$-actin polyclonal antibody (Actin C-11: sc-1615; Santa Cruz Biotechnology), as descibed above. Quantification of the intensity of Western blot signals was carried out by densitometric scanning using an image-analysis system (1-D Manager; TDI, Madrid, Spain), and values for the specific signal (PR) were normalized to those of the internal control ( $\beta$-actin) to express arbitrary units of relative expression.

\section{Statistical analysis}

Statistical analysis was performed by analysis of variance (ANOVA) to test for significant differences among groups. When significant differences existed, ANOVA was followed by the Student-Newman-Keuls multiple range test to compare means. The level of significance was taken to be $0 \cdot 05$ level.

\section{Results}

Effect of ER ligands on serum and pituitary LH levels in ovariectomized rats

Administration of EB, $1.5 \mathrm{mg} \mathrm{PPT}$, with or without DPN, and $3 \mathrm{mg}$ TX decreased serum LH concentrations in ovariectomized rats. The remaining treatments had no effect (Fig. 1, upper panel). Pituitary LH content in ovariectomized rats decreased significantly after treatment with EB, $1.5 \mathrm{mg}$ PPT, and $3 \mathrm{mg}$ TX only. The decreasing effect of $1.5 \mathrm{mg}$ PPT on LH pituitary content was blunted by the simultaneous administration of DPN (Fig. 1, lower panel). 


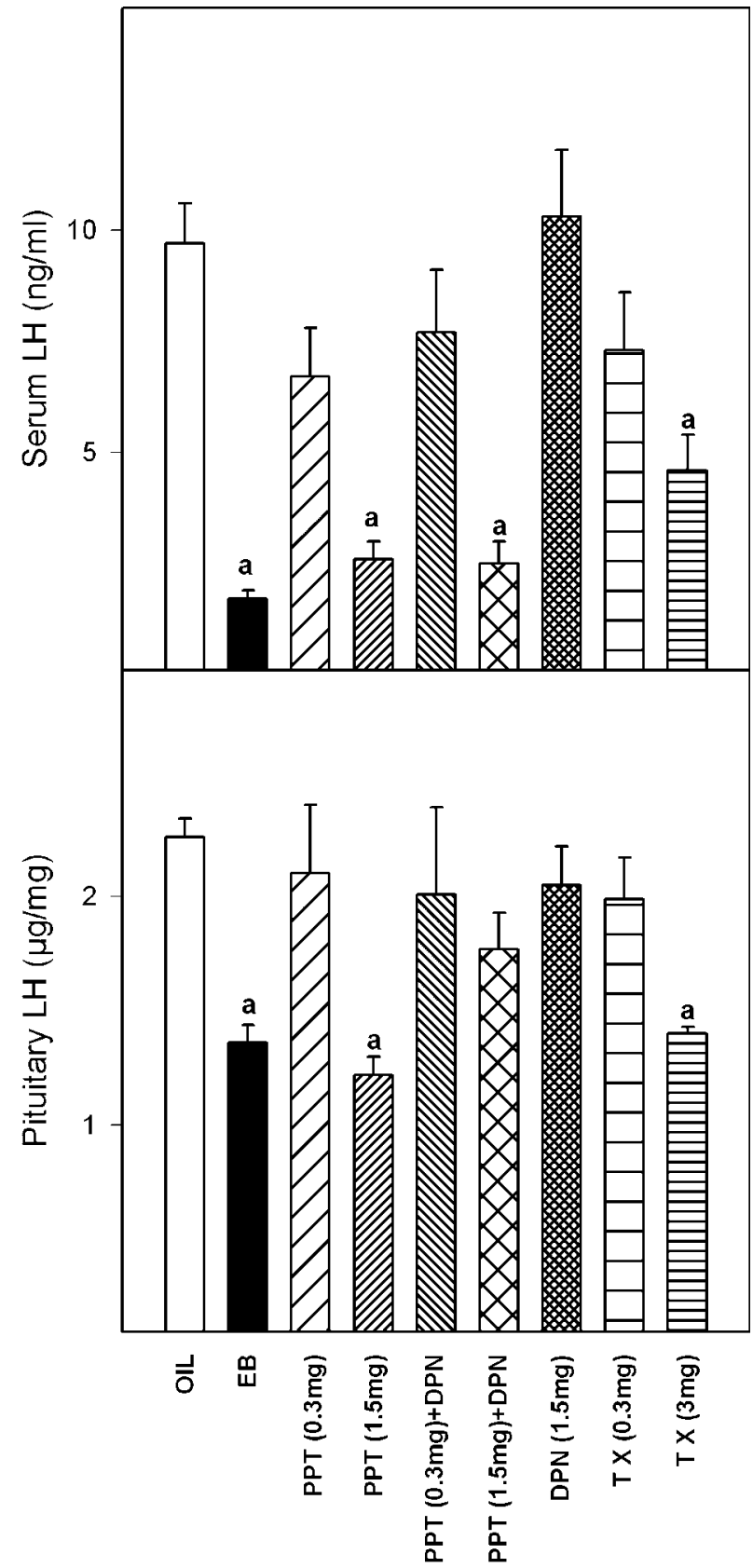

Figure 1 Serum concentration $(n=14)$ and pituitary content $(n=5)$ of $\mathrm{LH}$ in 2-week ovariectomized rats given $0.2 \mathrm{ml}$ oil, $25 \mu \mathrm{g} \mathrm{EB}$, 0.3 or $1.5 \mathrm{mg}$ PPT with or without $1.5 \mathrm{mg}$ DPN, $1.5 \mathrm{mg}$ of DPN alone, or 0.3 or $3 \mathrm{mg}$ of TX over 3 days. ${ }^{\text {a }} P<0.05$ versus ovariectomized rats injected with oil.

Structural and ultrastructural features of gonadotropes in ovariectomized rats treated with ER ligands

The percentage of gonadotropes found in this study $(14 \cdot 1 \pm 0 \cdot 2$ of the total pituitary cells), which was in agreement with that reported in gonadectomized rats
(Childs et al. 1982, Smith \& Keefer 1982), was not affected by any ER ligand treatments. On the contrary, differences in the size of gonadotropes were noted between control and experimental groups, although the sizes of other pituitary cells was not compromised (see legends of Figs 3 and 7 , below). Thus, pituitaries of the control group (ovariectomized rats injected with oil) had hypertrophied but not activated gonadotropes, while those of ovariectomized rats treated with ER ligands displayed both hypertrophied and activated gonadotropes (Figs. 2A and 3).

Structurally, hypertrophied gonadotropes were large, rounded cells with foamy or, more often, vacuolated cytoplasms and central or eccentric nuclei (Fig. 2A). Ultrastructurally, hypertrophied gonadotropes had dilated cisternae of RER, forming large vesicles, with irregular enlarged and prominent Golgi complexes. Eventually, cells with a single dilated RER vesicle with a homogeneous content of low electron density were observed (signet ring cells; Fig. 4A). Both the mean perimeter and the number of hypertrophied gonadotropes from ovariectomized rats treated with ER ligands were always smaller than those of hypertrophied gonadotropes from the control group of ovariectomized rats (Fig. 3). Thus, the mean perimeter of hypertrophied gonadotropes of the control group was $68 \cdot 3 \pm 0 \cdot 3 \mu \mathrm{m}$, which sharply contrasted with the mean perimeter of the other pituitary cells $(38.1 \pm 2.9 \mu \mathrm{m}$; see legend of Fig. 3), while the mean perimeter of hypertrophied gonadotropes from the experimental groups ranged from $65.3 \mu \mathrm{m}$ in OVX+TX $(0.3 \mathrm{mg})$ to $61.9 \mu \mathrm{m}$ in OVX+PPT $(1.5 \mathrm{mg})$-treated rats. Also, a decrease in the percentage of hypertrophied gonadotropes was noted in the experimetal groups: $4 \cdot 4 \%$ in OVX+PPT $(1.5 \mathrm{mg})$-treated rats to $11.1 \%$ in OVX+ TX $(0 \cdot 3 \mathrm{mg})$-treated rats with respect to ovariectomized+ oil-injected rats $(14 \cdot 1 \%)$.

Activated gonadotropes were characterized by the presence of PR at the nuclear level (Fig. 2B and C) and were exclusively found in the pituitaries of ER-ligandtreated rats. The number of activated gonadotropes and the intensity of staining were highest in rats injected with $1.5 \mathrm{mg}$ PPT (Figs 2B and 3) and lowest in rats injected with $0.3 \mathrm{mg}$ TX (Figs $2 \mathrm{C}$ and 3 ). The structural and ultrastuctural features of activated gonadotropes also varied and, overall, electron microscopy changes in RER, Golgi complex, and secretory vesicles in the gonadotrope in ovariectomized rats treated with ER ligands correlated well with those observed at light microscopic level (Figs. 2, 4, and 5). Structurally activated gonadotropes were round, ovoid, and polygonal cells, with vacuolated, foamy, or homogeneous cytoplasms and eccentric or central nuclei (Fig. 2B). Electron microscopy disclosed dilated RER cisternae forming from rounded (Figs 4B and C) to ovoid (Fig. 4D) and polygonal (Figs 4E and F) vesicles. Golgi complexes stood out more prominently in activated gonadotropes with ovoid and irregular vesicles 
(Fig. 4D) than in those with rounded, homogeneous vesicles (Figs $4 \mathrm{~B}$ and $\mathrm{C}$ ), while no differences in granulation were apparent. The perimeter of activated gonadotropes was always smaller than the perimeter of hypertrophied gonadotropes in any group of ER-ligandtreated rats. The perimeter threshold for the change
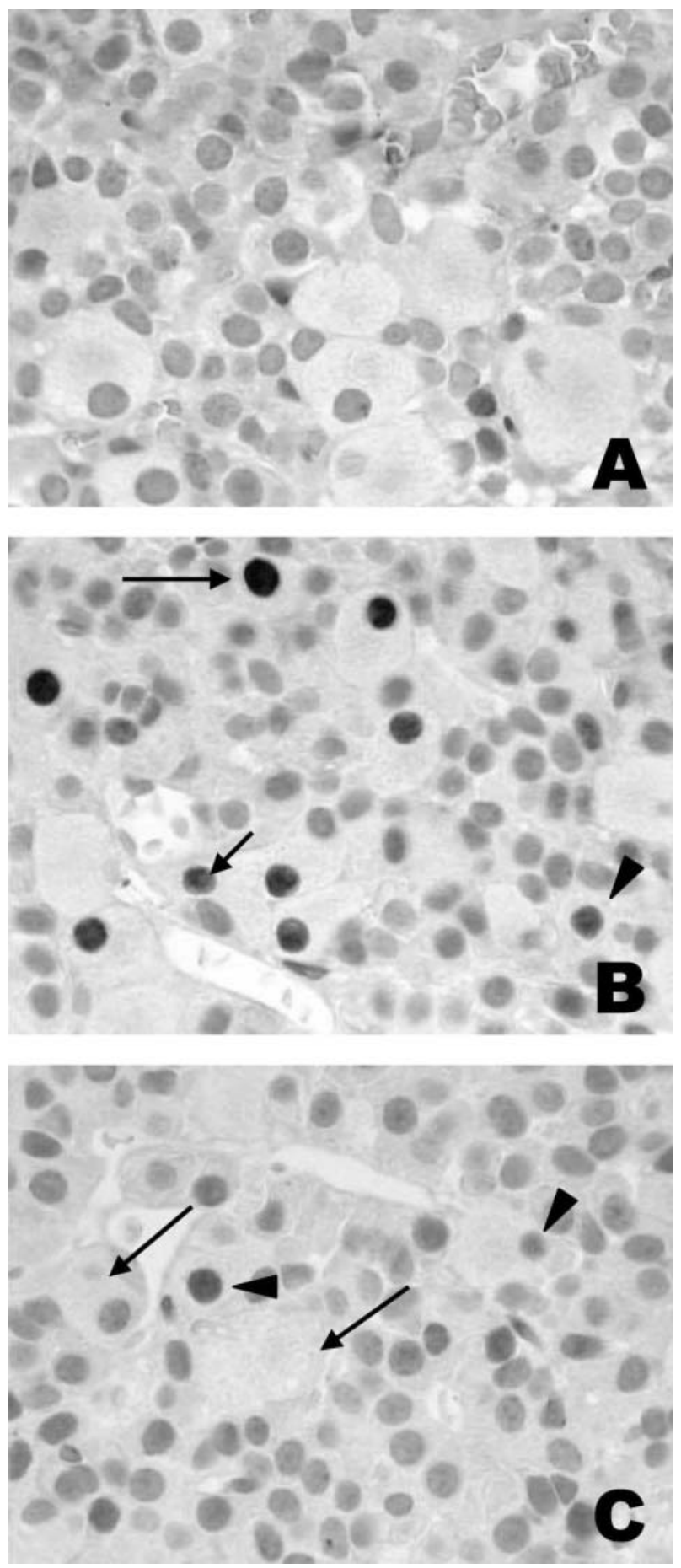

from hypertrophied to activated gonadotrope appeared to lie between 50 and $60 \mu \mathrm{m}$. The relative number of activated gonadotropes ranged from $3.7 \%$ in OVX+TX $(0.3 \mathrm{mg})$-treated rats to $10 \cdot 7 \%$ in OVX+PPT $(1.5 \mathrm{mg})-$ treated rats (Fig. 3). Both hypertrophied and activated gonadotropes from the OVX+EB-treated group and the OVX + PPT $(1.5 \mathrm{mg})+\mathrm{DPN}$-treated group of rats were very similar in terms of percentage and size (Fig. 3), as well as structural and ultrastuctural features (Figs $4 \mathrm{~B}$ and C). It is interesting to highlight that the administration of DPN to rats injected with 0.3 or $1.5 \mathrm{mg}$ PPT significantly blunted the oestrogen effects of PPT on the gonadotrope, both at the structural (Fig. 3) and ultrastuctural (Fig. 5) levels.

\section{Effect of ER ligands on PR protein expression in} ovariectomized rats

Western blot analysis of PR protein in the pituitary revealed an intense band of approximately $115 \mathrm{kDa}$, apparently corresponding to the B isoform of PR (PR-B), in keeping with previous studies (Guerra-Araiza et al. 2003; Fig. 6, upper panel). Semi-quantitative evaluation of the expression data showed a low to negligible PR-B signal in ovariectomized rats. In this model, administration of $\mathrm{EB}$ induced a significant increase in $\mathrm{PR}$ protein content, a response that was mimicked by administration of PPT at the doses of 0.3 and $1.5 \mathrm{mg}$. Likewise, DPN induced a modest but significant increase in PR-B protein levels; yet this response was significantly lower than that induced by PPT. Co-administration of PPT and DPN at doses of $1.5 \mathrm{mg}$ resulted in changes in PR-B levels over OVX values that were lower than those induced by administration of PPT alone (Fig. 6, lower panel). Finally, treatment with TX dose-dependently enhanced PR-B protein levels, as $0.3 \mathrm{mg}$ TX was ineffective, whereas $3 \mathrm{mg}$ TX increased PR-B content. However, the magnitude of the response to the highest dose of TX was

Figure 2 Structural features and PR-expression patterns of gonadotropes from 2-week ovariectomized rats injected over 3 days with different ER ligands (see legend of Fig. 1 for details of treatments). Avidin-biotin peroxidase complex

immunohistochemical technique, counterstaining with Mayer's haematoxylin, $\times 400$. (A) In ovariectomized rats injected with oil, the large, rounded cells with clear and vacuolated cytoplasm are hypertrophied gonadotropes. Nuclear staining with PR antibody is absent. (B) In ovariectomized rats treated with PTT (1.5 mg), immunoreactive products to PR antibody are seen in the nuclei of some cells (dark colour) which are thus identified as activated gonadotropes. The intensity of staining varies from high (long arrow) to medium (short arrow). Some activated gonadotropes are rounded with clear cytoplasm and some others are smaller and polygonal (arrowhead). (C) In ovariectomized rats treated with TX $(0.3 \mathrm{mg})$, large, rounded cells with clear, occasionally vacuolated cytoplasm are seen (arrows). Two of them show a faint nuclear staining (arrowheads). 


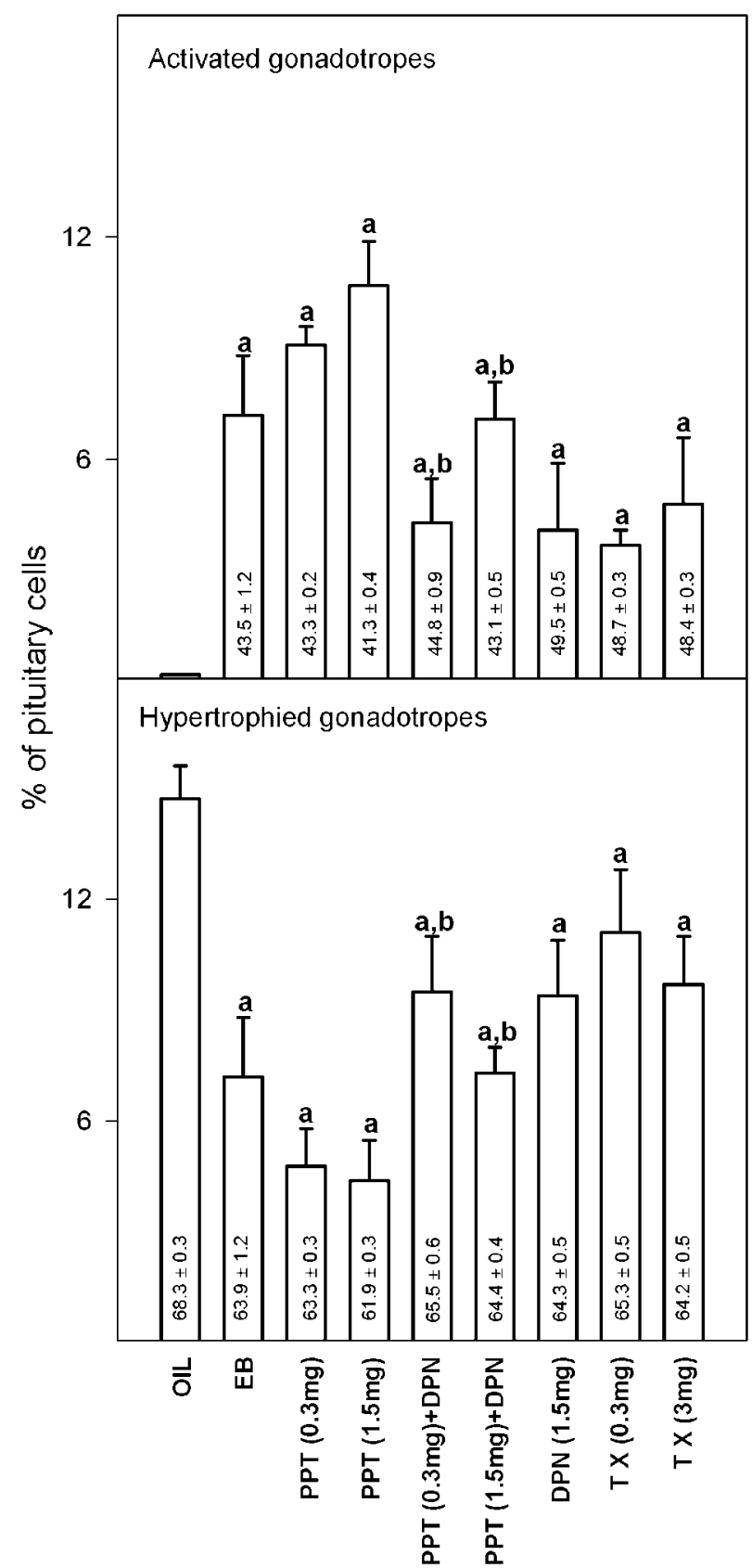

Figure 3 Relative number (\%) of pituitary cells showing (activated gonadotropes) or not showing (hypertrophied gonadotropes) immunohistochemical reaction to PR in pituitaries from 2-week ovariectomized rats injected over 3 days with different ER ligands (see legend of Fig. 1 for details of treatments). Values are means \pm S.E.M. from four hemipituitaries/group (20 fields of about 15 gonadotropes/rat). ${ }^{a} P<0.05$ versus ovariectomized rats injected with oil; ${ }^{b} P<0 \cdot 05$ versus values in pituitaries from ovariectomized rats injected only with 0.3 or $1.5 \mathrm{mg}$ PPT. Inside each bar is the mean \pm S.E.M. $(\mu \mathrm{m})$ of the gonadotrope perimeter. The average perimeter of the remaining pituitary cells $(85 \cdot 7 \pm 4 \cdot 0 \%)$ was $38 \cdot 1 \pm 2 \cdot 9 \mu \mathrm{m}$ and was not affected by ER ligand treatments.
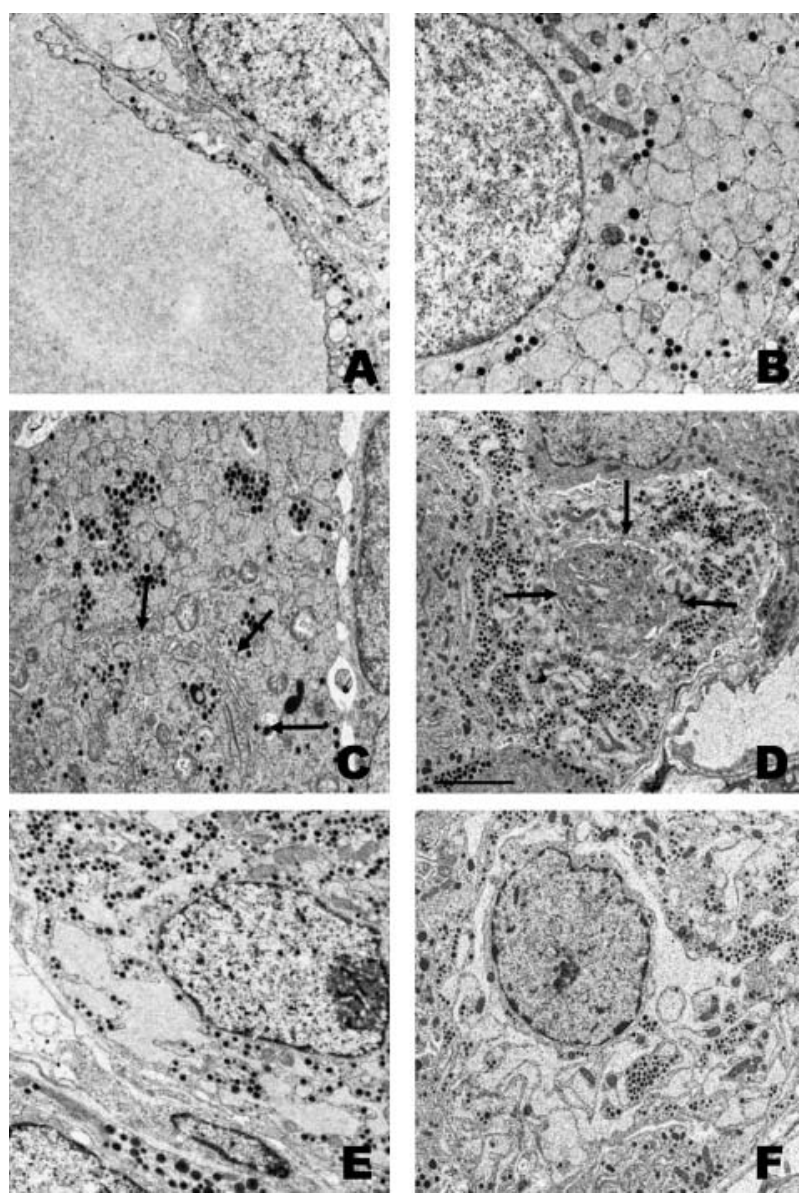

Figure 4 Ultrastructural features of activated gonadotropes from 2-week ovariectomized rats injected over 3 days with different ER ligands (see legend of Fig. 1 for details of treatments). (A) Signet ring cell in an ovariectomized rat injected with oil. A single, large RER vesicle of homogeneous, low electron density content is seen, $\times 15$ 000. (B) Gonadotrope with a vesiculated cytoplasm in an ovariectomized rat treated with EB. The vesicles are small, rounded and uniform in size and have a low electron density content. The nucleus has a rounded outline and secretory granules are scattered throughout the cytoplasm, $\times 15$ 000. (C) Gonadotrope in an ovariectomized rat injected with PPT $(1.5 \mathrm{mg})$ with a vesiculated cytoplasm similar to that shown in (B) and a visible Golgi complex (arrows). Secretory granules are scattered throughout the cytoplasm, $\times 4000$. (D) Gonadotrope in an ovariectomized rat injected with PPT $(1.5 \mathrm{mg})$ and DPN $(1.5 \mathrm{mg})$. The cytoplasm is vesiculated but vesicles are ovoid rather than rounded and their size is not homogeneous. It is also well granulated and an enlarged Golgi complex is seen (arrows), $\times 4000$. (E) Gonadotrope in an ovariectomized rat injected with DPN $(1.5 \mathrm{mg})$ with large, irregular vesicles of different sizes with few tenous strands of cytoplasm and granules between them. The nucleus is heterochromatic and has a large nucleolus, $\times$ 4000. (F) Gonadotrope of an ovariectomized rat injected with $3 \mathrm{mg}$ TX with dilated cisternae of RER forming a filigree in the cytoplasm, which is well granulated, $\times 4000$. 

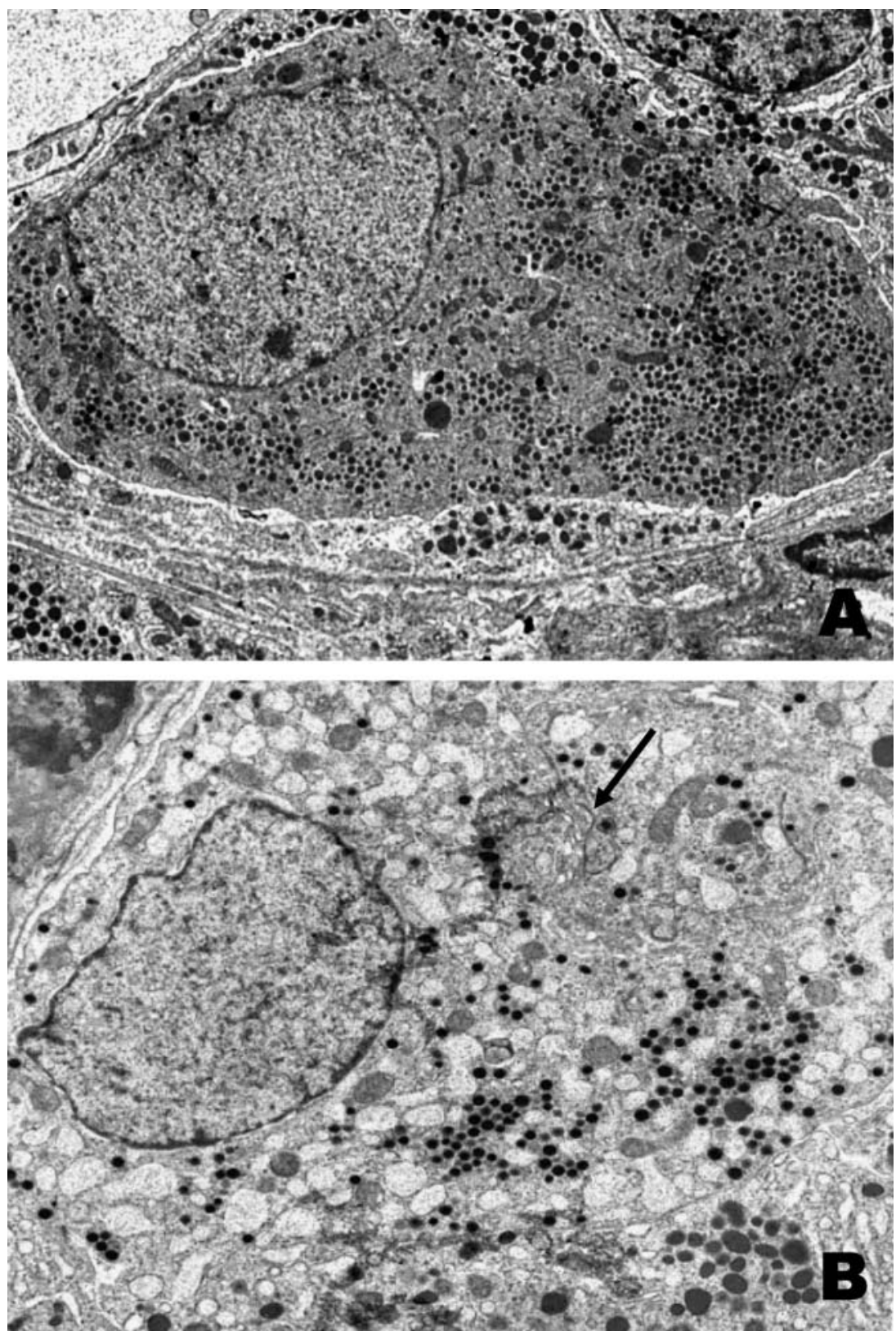

Figure 5 Micrographs showing comparative details of the effect of $1.5 \mathrm{mg}$ DPN on the ultrastuctural features of gonadotropes from ovariectomized rats treated with $1.5 \mathrm{mg}$ PPT (see legend of Fig. 1 for details of treatments). (A) Gonadotrope from an ovariectomized rat treated with PPT alone with a polygonal shape, an oval, euchromatic nucleus and a homogeneous cytoplasm. Secretory granules are scattered throughout the cytoplasm, $\times 7600$. (B) Gonadrotrope from an ovariectomized rat after the combined treatment with PPT and DPN shows an increase in cell size, a slightly irregular nucleus and a vesiculated cytoplasm. The vesicles are small, ovoid and nearly uniform in size and they virtually fill the cytoplasm. Granules are scattered between the vesicles throughout the cytoplasm and vesicles and cisternae of the Golgi complex are seen (arrow), $\times 7600$. 

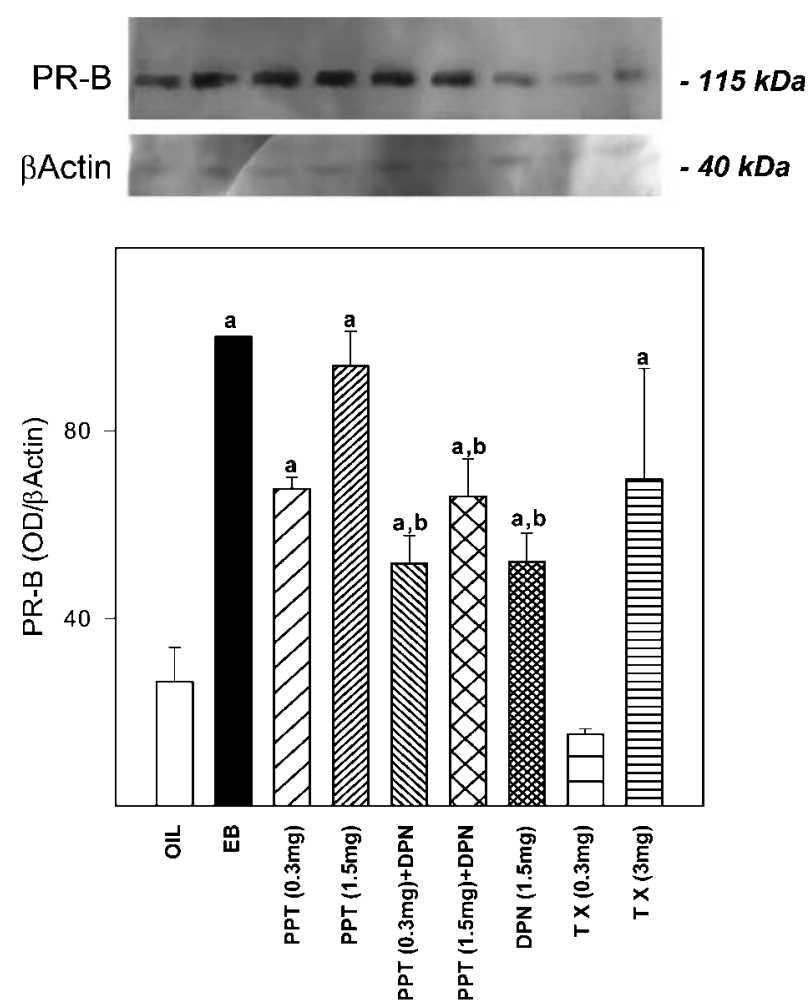

Figure 6 PR protein content in pituitary samples from 2-week ovariectomized rats injected over 3 days with different experimental ER ligands (see legend of Fig. 1 for details of treatments). In the upper panel, representative Western blots of $P R$ and $\beta$-actin are shown. Probing of blots with a specific anti-PR polyclonal antibody evidenced a single band of approximately $115 \mathrm{kDa}$, which corresponds to the predicted size of the PR-B isoform. Thereafter, blots were stripped and reprobed with $\beta$-actin antibody; a procedure which resulted in detection of a single band of the predicted size $40 \mathrm{kDa}$. The lower panel shows a compilation of semi-quantitative data of relative PR-B protein levels in the experimental samples. Data are means \pm S.E.M. from five independent Western blot assays. ${ }^{a} P<0.05$ versus ovariectomized rats injected with oil; ${ }^{b} P<0.05$ versus ovariectomized rats injected with $1.5 \mathrm{mg}$ PPT.

significantly lower than that induced by $1.5 \mathrm{mg}$ PPT (Fig. 6, lower panel).

Effect of different doses of DPN on gonadotropes in ovariectomized rats treated with $1.5 \mathrm{mg} P P T$

Figure 7 depicts the effect of increasing doses of DPN on the percentage and perimeter of activated and hypertrophied gonadotropes in ovariectomized rats injected over 3 days with $1.5 \mathrm{mg}$ PPT. Whereas the percentage of activated gonadotropes decreased, that of hypertrophied gonadotropes increased in a DPN dosedependent manner. Also, DPN blunted, in a dosedependent manner, the gonadotrope shrinkage induced by PPT in ovariectomized rats.

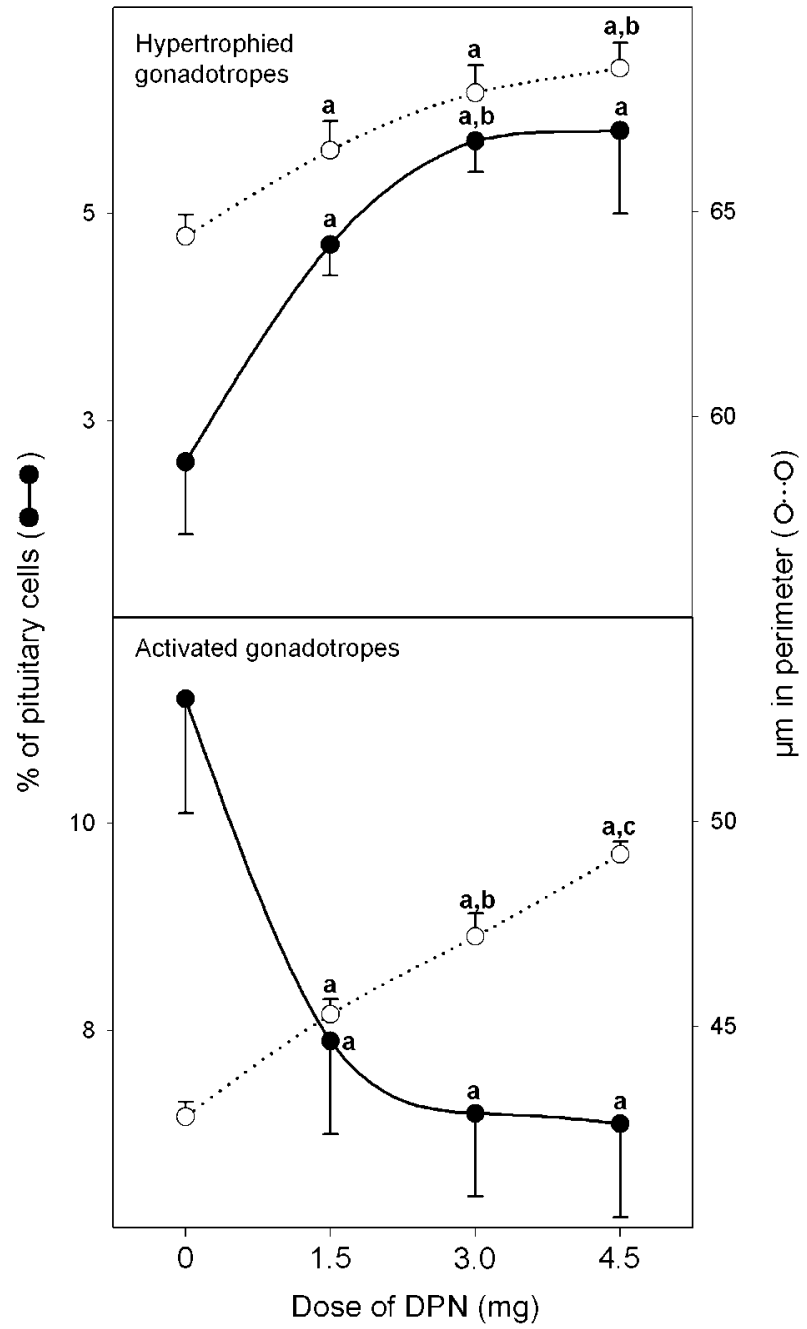

Figure 7 Relative number (\%) and average perimeter $(\mu \mathrm{m})$ of pituitary cells showing activated (lower panel) and hypertrophied (upper panel) gonadotropes in pituitaries from 2-week

ovariectomized rats injected over 3 days with $1.5 \mathrm{mg}$ PPT and with $0.2 \mathrm{ml}$ oil, $1.5,3.0$, or $4.5 \mathrm{mg}$ DPN. Values are means \pm S.E.M. from four rats (20 fields of about 15 gonadotropes/rat). ${ }^{a} P<0 \cdot 05$ versus ovariectomized+PPT rats injected with oil; ${ }^{b} P<0.05$ versus ovariectomized+PPT rats injected with $1.5 \mathrm{mg}$ DPN; ${ }^{\mathrm{C}} P<0.05$ versus ovariectomized+PPT rats injected with $3 \mathrm{mg}$ DPN. The average perimeter of the remaining pituitary cells $(86 \cdot 3+8 \cdot 0 \%)$ was $39 \cdot 9+4.9 \mu \mathrm{m}$, and was not affected by ER ligand treatments.

\section{Discussion}

The results of the present work showed that administration of ER $\alpha$-subtype-selective ligand PPT (Stauffer et al. 2000) in ovariectomized rats had oestrogen activity on all parameters of gonadotrope function analysed, whereas administration of ER $\beta$-subtype-selective ligand DPN (Meyers et al. 2001) mimicked all actions of PPT except the reduction of pituitary content and serum 
concentration of LH. The latter action, however, was the only one not affected when both ER ligands were administered simultaneously. Morphological parameters of gonadotrope function evaluated were qualitative characteristics of the membrane-enclosed intracellular organelles, gonadotrope size, and PR expression status. In fact, due to the pivotal role of PR in gonadotrope function in the rat (Fink 2000), we used the immunohistochemical expression of PR in gonadotropes to classify them as activated (with PR expression) or hypertrophied (without PR expression).

In the rat, the presence of $\mathrm{PR}$ in gonadotropes is an absolute requirement for full pituitary responsiveness to GnRH (Fink 1995, 2000). Strictly oestrogen-dependent PR (Fox et al. 1990) can be activated by the cognate ligand (Levine 1997) or, in a ligand-independent manner, by intracellular signalling of GnRH (Turgeon \& Waring 1994). In the absence of PR expression (Chappell et al. 1999, Bellido et al. 2003) or action (Sánchez-Criado et al. 2004) GnRH self-priming is absent; hence, the height of the LH surge and the ovulation rate are reduced (Rao \& Mahesh 1986, Sánchez-Criado et al. 1990, Chappell et al. 1999). A close inverse relationship was noted between gonadotrope size and PR expression. Gonadotropes below $50 \mu \mathrm{m}$ in perimeter always expressed PR (activated), while those greater than $60 \mu \mathrm{m}$ did not (hypertrophied). Thus, a clear cut-off of about $55 \mu \mathrm{m}$ in perimeter seemed to be the threshold for acquisition of the ability to express PR (Fig. 7) and, in consequence, full responsiveness to GnRH. Classification of gonadotropes on a purely morphological basis, regardless of whether they express PR or not (Sánchez-Criado et al. 2004), gives overlapping figures and may mask ER $\beta$ effects. The present experiments showed that the percentage of activated gonadotropes paralleled the pituitary content of PR protein in the different experimental groups, as gonadotropes are the only pituitary cell type expressing PR (Fox et al. 1990, Sánchez-Criado et al. 2005). Minor differences noted in PR levels determined by immunohistochemistry and Western blot, qualitative and semi-quantitative techniques, respectively, could be due to the higher sensitivity of immunohistochemistry, as revealed in $0.3 \mathrm{mg}$ TX-treated ovariectomized rats (Figs $2 \mathrm{C}$ and 3 ), and the heterogeneous distribution (Fig. 2B) of the same amount of PR protein among gonadotropes. Overall, PR protein levels were low in ovariectomized rats, high in ovariectomized rats injected with $\mathrm{EB}$ or PPT, and intermediate in ovariectomized rats given DPN or TX, as already described for PR mRNA (Bellido et al. 2003). Finally, and much more important, activation of ER $\beta$ with DPN reduced the effect of the potency-selective ER $\alpha$ agonist PPT on the number of gonadotropes expressing PR and pituitary content of PR protein in ovariectomized rats. In addition to these effects on PR expression, the results of the present study showed that activation of ER $\alpha$ with PPT reversed the effects of OVX on gonadotrope morphology and serum levels and pituitary content of LH. Activation of ER $\beta$ with DPN had only slight effects on gonadotrope morphological parameters, with no evidence of negative feedback on $\mathrm{LH}$ release. Concurrent activation of both ER isoforms by simultaneous administration of PPT and DPN had intermediate shrinking and morphological effects on hypertrophied gonadotropes and on pituitary LH content without affecting the negativefeedback effect of PPT on LH release.

Activation of ER $\alpha$ in ovariectomized rats seemed to be responsible for all actions of oestrogen in the gonadotrope: (i) negative feedback on $\mathrm{LH}$ release; (ii) induction of PR; and (iii) reorganization of the membrane-enclosed intracellular organelles and shrinkage of gonadotropes. Moreover, it has previously been shown that PPT induces in ovariectomized rats: (i) positive feedback on LH release, (ii) sensitization of gonadotropes to $\mathrm{GnRH}$, and (iii) PR-dependent (Chappell et al. 1999) GnRH self-priming (Sánchez-Criado et al. 2004). The results obtained here with TX, a selective oestrogen receptor modulator (SERM) that displays antagonist/agonist actions (McDonnell 1999, McDonnell et al. 2002), supported this role for ER $\alpha$. In the absence of the cognate ligand, TX induces PR expression and elicits GnRH self-priming (Bellido et al. 2003, Sánchez-Criado et al. 2005), most probably through the ER $\alpha$ isoform (Tzuckerman et al. 1994, SánchezCriado et al. 2005). The present results showed that $3 \mathrm{mg}$ TX, but not $0.3 \mathrm{mg}$, significantly reduced serum and pituitary levels of $\mathrm{LH}$ in ovariectomized rats, an obvious ER $\alpha$ effect, and reverted, in a dose-related manner, the effects of OVX on gonadotrope hypertrophy and PR expression. On the other hand, activation of $\operatorname{ER} \beta$ alone lacked both positive (Sánchez-Criado et al. 2004) and negative feedback effect on LH release (present results). In contrast with the lack of effect on pituitary content and serum concentration of $\mathrm{LH}, \mathrm{ER} \beta$ induced, in the absence of $\mathrm{ER} \alpha$, reorganization of the membrane-enclosed intracellular organelles (RER and Golgi complex) and shrinkage of gonadotropes.

Potentially more important were the findings of the simultaneous administration of PPT and DPN. These results demonstrated, for the first time, that activation of $\mathrm{ER} \beta$ with DPN reduced, in a dose-related manner, the shrinking effect of ER $\alpha$ activation on gonadotropes and on ER $\alpha$-stimulated PR levels. Also, DPN blunted the decreasing effect of PPT on pituitary LH content without influencing PPT effect on serum LH concentration. It is worth noting that daily administration of $25 \mu \mathrm{g} \mathrm{EB}$, the cognate ligand that activates both ER isoforms (McInerney et al. 1998, Hall \& McDonnell 1999) over 3 days, had a full suppressive effect on LH release in ovariectomized rats, whereas its effects on gonadotrope morphology, the number of gonadotropes expressing PR, and pituitary $\mathrm{LH}$ content were moderate and similar to those elicited by coactivation of $\operatorname{ER} \alpha$ and $\operatorname{ER} \beta$ with their selective agonists. The pharmacological doses of EB used in 
the present experiment shrinks gonadotropes almost to the size exihibited by pituitaries in intact, proestrous rat (Sánchez-Criado et al. 2005). The respective roles of $\mathrm{ER} \alpha$ and $\mathrm{ER} \beta$ in prolactin- and gonadotrophin-secreting cells have previously been investigated through the use of ER-knockout mice (Pelletier et al. 2003). However, the lack of either ER $\alpha$ or ER $\beta$ in ER-knockout models limits the study of physiological interaction between ER isoforms.

The majority of steroid receptors (glucocorticoid, mineral corticoid, androgen, progesterone and oestrogen) come in pairs, and evidence is accumulating to indicate that this is not a case of redundancy, but that it has a physiological modulatory meaning (Vegeto et al. 1993, Oakley et al. 1996, Paech et al. 1997, Hall \& McDonnell 1999, Conneely et al. 2001). In many contexts, ER $\beta$ appears to antagonize the actions of ER $\alpha$ in a ying-yang relationship (Paech et al. 1997, Hall \& McDonnell 1999, McDonnell et al. 2002, Weihua et al. 2003, Koehler et al. 2005). ER $\beta$ inhibits the stimulatory action of ER $\alpha$ on breast (Paruthiyil et al. 2004, Helguero et al. 2005), bone (Lindberg et al. 2003), uterus (Weihua et al. 2000, Frasor et al. 2003), and hair follicles (Ohnemus et al. 2005) in mice. The present results showed a similar relationship between ER $\alpha$ and $\operatorname{ER} \beta$ in the ovariectomized rat gonadotrope. In the absence of activation of $E R \alpha$, which predominates in the pituitary (Scully et al. 1997), activation of ER $\beta$ partially replaced its actions on gonadotrope shrinkage, reorganization of intracellular organelles, and PR expression. In the presence of activated ER $\alpha$, ER $\beta$ reduced the effects of ER $\alpha$ on gonadotrope morphology, PR expression, and pituitary LH content. On the contrary, activation of $\operatorname{ER} \beta$, either alone or in combination with $\mathrm{ER} \alpha$, did not prompt an inhibitory effect on serum LH concentration in ovariectomized rats. In addition, it has previously been shown that $\operatorname{ER} \beta$, alone or combined with ER $\alpha$, has no effects on basal or GnRH-stimulated LH release nor on GnRH self-priming (Sánchez-Criado et al. 2004) despite its effects on PR. All these results implied that release and the rest of the secretory events in the gonadotrope are differentially ER-regulated events.

In summary, reorganization of the membrane-enclosed intracellular organelles, shrinkage of the gonadotrope, PR expression, and reduction of pituitary LH content in ovariectomized rats are positively regulated by $E R \alpha$, and these actions of ER $\alpha$ are inhibited by ER $\beta$. In the absence of $\operatorname{ER} \alpha$ activity, activation of $\operatorname{ER} \beta$ partially replaced these actions. Regulated exocytosis, the final process in the secretory pathway, is dependent exclusively on ER $\alpha$ priming. Thus, it appeared that the presence of $\operatorname{ER} \alpha$ and $\mathrm{ER} \beta$ in the gonadotrope is not a case of redundant regulatory effects of oestrogen, but rather the results suggested the existence of a more refined level of modulation of oestrogen signalling at the level of the gonadotrope.

\section{Acknowledgements}

This work was subsidized by grants (BFI2002-0045, BFU2005-01443 and AGL2003-0603) from DGICYT, Spain. The authors are grateful to the National Hormone and Pituitary Program, NIAMD, Bethesda MD, USA, for the LH RIA kit. The authors declare that there is no conflict of interest that would prejudice the impartiality of this scientific work.

\section{References}

Bellido C, Martín de las Mulas J, Tena-Sempere M, Aguilar R, Alonso R \& Sánchez-Criado JE 2003 Tamoxifen induces gonadotropin-releasing hormone self-priming through an estrogen-dependent progesterone receptor expression in the gonadotrope of the rat. Neuroendocrinology 77 424-434.

Blanco A, Agüera E, Flores R, Artacho-Pérula E \& Monterde JG 2001 Morphological and quantitative study of the Leydig cells of pigs fed with anabolic doses of clenbuterol. Research in Veterinary Science 71 85-91.

Chappell PE, Schneider JS, Kim P, Xu M, Lydon JP, O'Malley BW \& Levine JE 1999 Absence of gonadotropin surges and gonadotropin-releasing hormone self-priming in ovariectomized (OVX), estrogen $\left(\mathrm{E}_{2}\right)$-treated, progesterone receptor knockout (PRKO) mice. Endocrinology 140 3653-3658.

Childs GV 1986 Functional ultrastucture of gonadotropes: a review. In Current Topics in Neuroendocrinology, vol 7, pp 49-97. Eds D Ganten \& D Pfaff. Berlin: Springer-Verlag.

Childs GV, Ellison DG, Lorenzen JR, Collins TH \& Schwartz NB 1982 Immunocytochemical studies of gonadotropin storage in developing castration cells. Endocrinology 111 1318-1328.

Conneely OM, Mulac-Jericevic B, Lydon JP \& De Mayo FJ 2001 Reproductive functions of the progesterone receptors isoforms: lessons from knock-out mice. Molecular and Cellular Endocrinology 179 97-103.

Fink G 1979 Feedback actions of target hormones on hypothalamus and pituitary with special reference to gonadal steroids. Annual Reviews of Physiology 41 571-585.

Fink G 1988 Gonadotropin secretion and its control. In The Physiology of Reproduction, pp 1349-1377. Eds E Knobil \& J Neill. New York: Raven Press.

Fink G 1995 The self-priming effect of LHRH: a unique servomechanism and possible cellular model for memory. Frontiers in Neuroendocrinology 16 183-190.

Fink G 2000 Neuroendocrine regulation of pituitary function. In Neuroendocrinology in Physiology and Medicine, pp 107-183. Eds PM Conn \& ME Freeman. New Jersey: Humana Press.

Fox SR, Harlan RE, Shievers BD \& Pfaff DW 1990 Chemical characterization of neuroendocrine targets for progesterone in the female rat brain and pituitary. Neuroendocrinology 51 276-283.

Frasor J, Barnett DH, Danes JM, Hess R, Parlow AF \& Katzenellenbogen BS 2003 Response-specific and ligand dose-dependent modulation of estrogen receptor (ER) alpha activity by ERbeta in the uterus. Endocrinology 144 3159-3166.

Garner LL \& Blake ChA 1981 Ultrastructural, immunocytochemical study of the LH secreting cell of the rat anterior pituitary gland: changes occurring after ovariectomy. Biology of Reproduction 24 461-474.

Genbacev O \& Pantic V 1975 Pituitary cell activities in gonadectomized rats treated with estrogen. Cell and Tissue Research 157 273-282.

Guerra-Araiza C, Villamar-Cruz O, González-Arenas A, Chavira R \& Camacho-Arroyo I 2003 Changes in progesterone receptor isoforms content in the rat brain during the oestrous cycle and after 
oestradiol and progesterone treatments. Journal of Neuroendocrinology 15 984-990.

Hall JM \& McDonnell DP 1999 The estrogen receptor $\beta$-isoform $(\mathrm{ER} \beta)$ of the human estrogen receptor modulates ER $\alpha$ transcriptional activity and is a key regulator of cellular response to estrogen and antiestrogens. Endocrinology 140 5566-5578.

Helguero LA, Faulds MH, Gustafsson J-A \& Haldosén L-A 2005 Estrogen receptor alfa $(\mathrm{ER} \alpha)$ and beta $(\mathrm{ER} \beta)$ differentially regulate proliferation and apoptosis of the normal mammary epithelial cell line HC11. Oncogene 24 6605-6616.

Keightley M-C 1998 Steroid receptor isoforms: exception or rule? Molecular and Cellular Endocrinology 137 1-5.

Koehler KF, Helguero LA, Haldosén L-A, Warner M \& Gustafsson J-A 2005 Reflections on the discovery and significance of estrogen receptor $\beta$. Endocrine Reviews 26 465-478.

Kuiper GG, Carlsson B, Grandien K, Enmark E, Haggblad J, Nilsson S \& Gustafsson J-A 1997 Comparison of the ligand binding specificity and transcript tissue distribution of estrogen receptors $\alpha$ and $\beta$. Endocrinology 138 863-870.

Levine JE 1997 New concepts of the neuroendocrine regulation of gonadotropin surges in rats. Biology of Reproduction 56 293-302.

Lindberg MK, Moverare S, Skrtic S, Gao H, Dahlman-Wright K, Gustafsson J-A \& Ohlsson C 2003 Estrogen receptor (ER)-beta reduces ER alpha-regulated gene transcrition, supporting a 'ying yang' relationship between ERalpha and ERbeta in mice. Molecular Endocrinology 17 203-208.

Low O 1988 Morphometric investigations on endocrine glands. VII. The influence of some estrogens on formation of castration cells in the anterior pituitary of rats. Experimental Pathology 35 149-157.

McDonnell DP 1999 The molecular pharmacology of SERMs. Trends in Endocrinology and Metabolism 10 301-311.

McDonnell DP, Connor CE, Wijayartne A, Chang CHY \& Norris JD 2002 Definition of the molecular and cellular mechanism underlying the tissue-selective estrogen receptor modulators. Recent Progress in Hormone Research 57 295-316.

McInerney EM, Weis KE, Sun J, Mosselman S \& Katzenellenbogen BS 1998 Transcription activation by the human estrogen receptor subtype $\beta(\operatorname{ER} \beta)$ studied with $\operatorname{ER} \beta$ and $\operatorname{ER} \alpha$ receptor chimeras. Endocrinology 139 4513-4522.

Meyers MJ, Sun J, Carlson KE, Marriner A, Katzenellenbogen BS \& Katzenellenbogen JA 2001 Estrogen receptor- $\beta$ potency-selective ligands: structure-activity relationship studies of diarylpropionitriles and their acetylene and polar analogues. Journal of Medicinal Chemistry 44 4230-4251.

Mitchner NA, Garlick C \& Ben-Jonathan N 1998 Cellular distribution and gene regulation of estrogen receptor $\alpha$ and $\beta$ in the rat pituitary gland. Endocrinology 139 3976-3983.

Murdoch FE \& Gorski J 1991 The role of ligand in estrogen receptor regulation of gene expression. Molecular and Cellular Endocrinology 78 C103-C108.

Oakley RH, Sar M \& Cidlowsk JA 1996 The human glucocorticoid receptor beta isoform. Expression, biochemical properties, and putative function. Journal of Biological Chemistry 271 9550-9559.

Ohnemus U, Uenalan M, Conrad F, Handjiski B, Mecklenburg L, Nakamura M, Izunza J, Gustafsson J-A \& Paus R 2005 Hair cycle control by estrogens: cotagen induction via estrogen receptor (ER) $-\alpha$ is checked by ER $\beta$ signaling. Endocrinology 146 1214-1225

Paech K, Well P, Kuiper GGJM, Nilsson S, Gustafsson JA, Kushner PJ \& Scanlan TS 1997 Differential ligand acrtivation of estrogen receptors ER $\alpha$ and ER $\beta$ at AP1 sites. Science 277 1508-1510.

Paruthiyil S, Parmar H, Kerekatte V, Cunha GR, Firestone GL \& Leitman DC 2004 Estrogen receptor beta inhibits human breast cancer cell prolifaration and tumor formation by causing G2 cell cycle arrest. Cancer Research 64 423-428.

Pelletier G, Li S, Phaneuf D, Martel C \& Labrie F 2003

Morphological studies of prolactin-secreting cells in estrogen receptor $\alpha$ and estrogen receptor $\beta$ knockout mice. Neuroendocrinology 77 324-333.

Pierce JG 1988 Gonadotropins: chemistry and biosynthesis. In The Physiology of Reproduction, pp 1335-1348. Eds E Knobil \& J Neill. New York: Raven Press.

Rao IM \& Mahesh VB 1986 Role of progesterone in the modulation of the preovulatory surge of gonadotropins and ovulation in the pregnant mare's serum gonadotropin-primed immature rat and the adult rat. Biology of Reproduction 35 1154-1161.

Sánchez-Criado JE, Bellido C, Galiot F, López FJ \& Gaytán F 1990 A possible dual mechanism of the anovulatory action of antiprogesterone RU486 in the rat. Biology of Reproduction 42 877-886.

Sánchez-Criado JE, Martín de las Mulas J, Bellido C, Tena-Sempere M, Aguilar R \& Blanco A 2004 Biological role of pituitary estrogen receptors $\operatorname{ER} \alpha$ and $\operatorname{ER} \beta$ on progesterone receptor expression and action and on gonadotropin and prolactin secretion in the rat. Neuroendocrinology 79 247-258.

Sánchez-Criado JE, Martín de las Mulas J, Bellido C, Aguilar R \& Garrido-Gracia JC 2005 Gonadotrope oestrogen receptor- $\alpha$ and $-\beta$ and progesterone receptor immunoreactivity after ovariectomy and exposure to oestrdaiol benzoate, tamoxifen or raloxifene in the rat: correlation with LH secretion. Journal of Endocrinology 184 59-68.

Scully KM, Gleiberman AS, Lindzey J, Lubahn DB, Korach KS \& Rosenfeld MG 1997 Role of estrogen receptor- $\alpha$ in the anterior pituitary gland. Molecular Endocrinology 11 674-681.

Smith PF \& Keefer DA 1982 Immunohistochemical and ultrastructural identification of mitotic cells in the pituitary gland of ovariectomized rats. Journal of Reproduction and Fertility 66 383-389.

Stauffer SR, Coletta CJ, Tedesco R, Nishiguchi G, Carlson K, Sun J, Katzenellenbogen BS \& Katzenellenbogen JA 2000 Pyrazole ligands: structure-affinity/activity relationships and estrogen receptor- $\alpha$-selective agonist. Journal of Medicinal Chemistry 43 4934-4947.

Tena-Sempere M, Navarro VM, Mayen A, Bellido C \& Sánchez-Criado JE 2004 Regulation of estrogen receptor (ER) isoforms messenger RNA expression by different ER ligands in the female rat pituitary. Biology of Reproduction 70 671-678.

Turgeon JL \& Waring DW 1994 Activation of the progesterone receptor by the gonadotropin-releasing hormone self-priming signaling pathway. Molecular Endocrinology 6 860-869.

Tzuckerman MT, Esty A, Santiso-Mere D, Danielian P, Parker MG, Stein RB, Pike J \& McDonnell DP 1994 Human estrogen receptor transcriptional capacity is determined by both cellular and promoter context and mediated by two functionally distinct intramolecular regions. Molecular Endocrinology 8 21-30.

Vaillant C, Chesnel F, Schausi D, Tiffoche C \& Thieulant ML 2002 Expression of estrogen receptor subtypes in rat pituitary gland during pregnancy and lactation. Endocrinology 134 4249-4258.

Vegeto E, Shahbaz MM, Wen DX, Goldman ME, O'Malley BW \& McDonnell DP 1993 Human progesterone receptor A form is a cell and promoter specific repressor of human progesterone receptor B function. Molecular Endocrinology 7 1244-1255.

Weihua Z, Saji S, Mä kinen S, Cheng G, Jensen EV, Warner M \& Gustafsson J-A 2000 Estrogen receptor (ER) $\beta$, a modulator of ER $\alpha$ in the uterus. PNAS 97 5936-5941.

Weihua Z, Andersson S, Cheng G, Simpson ER, Warner M \& Gustafsson J-A 2003 Update on estrogen signaling. FEBS Letters $54617-24$.

Received 3 October 2005

Accepted 3 November 2005

Made available online as an Accepted Preprint 21 November 2005 